\section{Hyponatraemia during treatment with chlorpropamide and Moduretic (amiloride plus hydrochlorothiazide)}

Chlorpropamide occasionally causes low serum sodium concentrations, and thiazide diuretics commonly do so. When a thiazide is combined with the potassium sparing diuretic amiloride, urinary sodium excretion is increased, ${ }^{1}$ enhancing the risk of hyponatraemia. ${ }^{2}$ We describe eight patients with symptomatic hyponatraemia who were taking both chlorpropamide and Moduretic (amiloride $5 \mathrm{mg}$ plus hydrochlorothiazide $50 \mathrm{mg}$ ). In addition, we measured serum sodium concentrations in patients attending a diabetic clinic.

\section{Case reports}

Over five years we collected eight cases of hyponatraemia in patients concurrently taking chlorpropamide and Moduretic, seven of whom were admitted as emergencies (four under AMZ). The table gives relevant details. At presentation none of the patients were dehydrated or oedematous and none were taking excessive doses of the drugs. Hyponatraemia was severe: the single outpatient had a serum sodium concentration of $129 \mathrm{mmol}(\mathrm{mEq}) / 1$, but the highest concentration in an inpatient was $122 \mathrm{mmol} / \mathrm{l}$. In two cases epileptic seizures supervened.

In four patients we knew the serum sodium concentration before they had started the second drug, and in three this was normal. In two patients other factors may have contributed to their hyponatraemia. One of these patients was mildly hypothyroid and taking phenformin. The other was taking bendrofluazide $10 \mathrm{mg}$ daily, but her serum sodium concentration returned to normal after Moduretic was stopped.

All the patients were managed by stopping the offending drugs, although two continued taking chlorpropamide. Only two needed more active management. One, in status epilepticus, was given intravenous hypertonic saline and demethylchlortetracycline, which was also given to another patient. Clinical and biochemical improvement was rapid. An elderly woman (case 2), who had been confused and off balance for four months, became mobile and orientated five days after stopping the drugs.

Patients attending diabetic clinic-Of the patients aged over 40 attending our diabetic clinic, 64 were taking chlorpropamide, 20 Moduretic, and 289 neither. The mean (SD) serum sodium concentrations were $138.8(3.7)$ $\mathrm{mmol} / \mathrm{l}$ in the group taking chlorpropamide, $138.1(3.0) \mathrm{mmol} / 1$ in the group taking Moduretic, and $139.7(3.6) \mathrm{mmol} / 1$ in the group not taking chlorpropamide or Moduretic. The mean concentrations in the groups taking chlorpropamide and Moduretic were each significantly lower than the mean in the group not taking the drugs $(\mathrm{p}<0.05$; one tailed $t$ test).

\section{Comment}

Moduretic and chlorpropamide are widely used. A patient taking both is receiving three agents, each of which can depress serum sodium concentration. In about half of the reported cases of hyponatraemia induced by chlorpropamide the patients have simultaneously been taking diuretics. ${ }^{3}$ Synergism between chlorpropamide and a thiazide has been described in one patient in whom the hyponatraemic effect of chlorpropamide and a diuretic together was greater than the sum of the effects of each drug used separately. ${ }^{4}$ Our experience suggests that hyponatraemia due to this combination may not be as rare as previously thought, though we have found only one other report of hyponatraemia in a patient taking chlorpropamide and Moduretic. It might be argued that Moduretic alone caused the hyponatraemia in six of our eight patients. Nevertheless, the data on the two remaining patients suggest that both drugs were important. The serum sodium concentration in one of these patients dropped by $5 \mathrm{mmol} / 1$ (to 135 $\mathrm{mmol} / \mathrm{l}$ ) when Moduretic was given and by a further $19 \mathrm{mmol} / \mathrm{l}$ when chlorpropamide was added. The second patient had hypo- natraemia while taking chlorpropamide with a serum sodium concentration of $130 \mathrm{mmol} / \mathrm{l}$, which dropped a further $13 \mathrm{mmol} / \mathrm{l}$ when Moduretic was added. Our experience suggests that the combination of chlorpropamide and Moduretic is potentially dangerous.

Several of these cases have been reported to the Committee on Safety of Medicines, which has not previously been notified of this interaction. The manufacturer of Moduretic has also been informed.

In our study of diabetics aged over $\mathbf{4 0}$ we found that the mean serum sodium concentration in patients taking chlorpropamide was 0.9 $\mathrm{mmol} / \mathrm{l}$ lower than in the controls, and in patients taking Moduretic it was $1.6 \mathrm{mmol} / \mathrm{l}$ lower-that is, over $10 \%$ of the normal range. This suggests that both chlorpropamide and Moduretic may reduce mean sodium concentrations in diabetics.

We thank Professor R Hoffenberg, Dr A D Wright, and Dr C W F Clarke for permission to publish details of their cases and Mrs K Nock for typing the manuscript.

1 Kampffmeyer $\mathrm{H}$, Conway' $J$. The antihypertensive and diuretic effects of amiloride and its combination with hydrochlorthiazide. Clin Pharmacol Ther 1968;9: and its

2 Sunderam SG, Mankikar GD. Hyponatraemia in the elderly. Age Ageing 1983; 12:77-80.

3 Bründler $\dot{H}$, Berger W. Hyponatriämie und Hypoglykämie unter Behandlung mit Chlorpropamid. Schweiz Med Wochenschr 1978;108:1035-40

4 Fichman MP, Vorherr H, Kleeman CR, Telfer N. Diuretic induced hyponatraemia. Ann Intern Med 1971;75:853-63.

5 Polanska AI, Baron DN. Hyponatraemia associated with hydrochlorothiazide treatment. Br Med f 1978;i:175.

(Accepted 26 fune 1984)

Wordsley Hospital, Stourbridge, W Midlands DY8 5QX

A M ZALIN, MD, FRCP, consultant physician

C E HUTCHINSON, BSC, MB, senior house officer in medicine

$M$ JONG, MB, MRCP, senior house officer in medicine

Department of Hospital Statistics, Queen Elizabeth Hospital, Birmingham

K MATTHEWS, HND, statistical assistant

Correspondence to: Dr A M Zalin.

\section{$\beta \quad$ Blockers and verapamil: a cautionary tale}

In the treatment of angina pectoris both $\beta$ adrenoceptor blocking agents and verapamil (a calcium antagonist) have been shown to be effective. It is recognised that these drugs should not be administered together intravenously, and nor should patients having chronic oral treatment with one agent receive the other intravenously. ${ }^{1}$ Nevertheless, whether $\beta$ blockers and verapamil should be prescribed in combination orally remains a subject for debate. ${ }^{23}$

We describe a patient with no evidence of obstructive coronary artery disease who developed complete heart block, apparently as a result of this drug combination.

\section{Case report}

A 44 year old man presented with a three year history of central chest pain occurring both on exertion and at rest. He obtained unreliable relief from trinitrin and had had several hospital admissions on account of severe

\begin{tabular}{|c|c|c|c|c|c|c|c|c|}
\hline \multirow[b]{2}{*}{$\begin{array}{l}\text { Case } \\
\text { No }\end{array}$} & \multirow[b]{2}{*}{$\begin{array}{c}\text { Age } \\
\text { (years) }\end{array}$} & \multirow[b]{2}{*}{ Sex } & \multicolumn{2}{|c|}{ Chlorpropamide } & \multirow[b]{2}{*}{$\begin{array}{l}\text { Duration of } \\
\text { treatment with } \\
\text { Moduretic }\end{array}$} & \multirow[b]{2}{*}{ Presenting features } & \multicolumn{2}{|c|}{$\begin{array}{c}\text { Serum sodium } \\
\text { concentration (mmol/l) }\end{array}$} \\
\hline & & & $\begin{array}{c}\text { Duration } \\
\text { of treatment }\end{array}$ & Dose (mg) & & & At presentation & Finally \\
\hline $\begin{array}{l}1 \\
2 \\
3 \\
4 \\
5 \\
6 \\
7 \\
8\end{array}$ & $\begin{array}{l}69 \\
73 \\
77 \\
74 \\
63 \\
46 \\
57 \\
62\end{array}$ & $\begin{array}{l}\mathrm{M} \\
\mathrm{F} \\
\mathrm{M} \\
\mathrm{F} \\
\mathrm{F} \\
\mathrm{F} \\
\mathrm{F} \\
\mathrm{M}\end{array}$ & $\begin{array}{l}8 \text { years } \\
10 \text { years } \\
7 \text { months } \\
9 \text { days } \\
20 \text { days } \\
5 \text { years } \\
13 \text { years } \\
11 \text { years }\end{array}$ & $\begin{array}{l}500 \\
500 \\
500 \\
500 \\
250 \\
250 \\
250 \\
200\end{array}$ & $\begin{array}{l}4 \text { days } \\
11 \text { months } \\
7 \text { months } \\
4 \text { years } \\
12 \text { months } \\
3 \text { weeks } \\
3 \text { years } \\
3 \text { weeks }\end{array}$ & $\begin{array}{l}\text { Malaise, postural hypotension, vomiting } \\
\text { "Going off her feet" for } 4 \text { months, confusion for } 4 \text { weeks } \\
\text { Confusion for } 4 \text { weeks } \\
\text { Weakness, vomiting, headache } \\
\text { Malaise } \\
\text { Status epilepticus } \\
\text { Grand mal fit } \\
\text { Malaise, nausea, headache }\end{array}$ & $\begin{array}{l}116 \\
113 \\
118 \\
116 \\
129 \\
108 \\
122 \\
117\end{array}$ & $\begin{array}{l}137 \\
138 \\
139 \\
138 \\
139 \\
135 \\
141 \\
142\end{array}$ \\
\hline
\end{tabular}


chest pain. The resting electrocardiogram had always been normal. He smoked 20 cigarettes daily. Physical examination was unremarkable, his blood pressure being $130 / 80 \mathrm{~mm} \mathrm{Hg}$. An exercise electrocardiogram and thallium reperfusion scan result were normal. In spite of atenolol $(100 \mathrm{mg}$ daily) and verapamil ( $360 \mathrm{mg}$ daily) his symptoms became increasingly frequent and effort tolerance declined. Coronary angiography, performed in June 1983, showed normal vessels with a dominant right coronary artery; left ventricular function was normal.

In August 1983, while still receiving atenolol and verapamil, he was readmitted after further chest pain and syncope. He showed complete heart block with a ventricular rate of $40 / \mathrm{min}$. After pacing for 24 hours the heart reverted to sinus rhythm; there was no evidence of a myocardial infarction. One month later the electrocardiogram was normal both at rest and on exercise. The results of thallium-201 scintigraphy was normal at peak exercise, five hours after exercise, and during a cold pressor test.

He is currently having no treatment and still has intermittent chest pain, not always related to exertion. His bundle electrocardiography showed a normal $\mathrm{H}-\mathrm{V}$ interval of 40 milliseconds. Rapid atrial pacing failed to induce either chest pain or Wenckebach phenomenon. Corrected sinus node recovery time was normal. An $M$ mode echocardiogram was normal.

\section{Comment}

The cause of this patient's chest pain remains uncertain. He had no evidence of obstructive coronary artery disease or of myocardial infarction. Coronary artery spasm has not been excluded, although abnormalities might have been expected in electrocardiograms taken during pain or the cold pressor test. He has no evidence of cardiomyopathy or myocarditis. The most likely cause of the transient episode of complete heart block was the concurrent administration of atenolol and verapamil. Without such treatment atrioventricular conduction is normal. For ethical reasons we are unwilling to restudy conduction after further administration of these agents.

Despite the theoretical risks of giving two drugs, both with negative chronotropic and inotropic effects, some authors have suggested that this combination of drugs is safe in selected patients-that is, those without conduction disorders or left ventricular dysfunction. The manufacturers have no report of such an occurrence, and combination treatment has been shown to be more effective than either drug used alone. As this case illustrates, however, even these criteria may not prevent the development of an iatrogenic complication. ${ }^{4}$ When using these agents together caution is necessary, and the regimen of Bala Subramanian would be appropriate. ${ }^{2}$

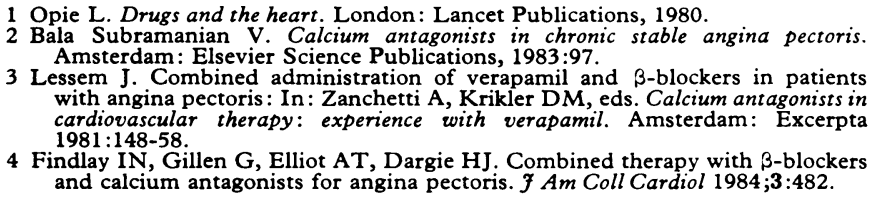

(Accepted 15 fune 1984)

Department of Medical Cardiology, Royal Infirmary, Glasgow G4 OSF

S J HUTCHISON, MRCP, registrar

A R LORIMER, MD, FRCP, consultant cardiologist

Department of Medicine, Royal Alexandria Infirmary, Paisley A LAKHDAR, MRCP, registrar

S G MCALPINE, FRCP, consultant physician

Correspondence to: Dr S J Hutchison.

\section{Infantile colic and parental smoking}

Infantile colic is very common and usually presents as paroxysmal screaming with clenched fists, legs drawn up, and a red face. The belief that crying occurs mainly in the evening was not confirmed in population surveys. ${ }^{1}$ The symptoms are thought to result from vigorous gastrointestinal contractions, but almost nothing is known about the cause. ${ }^{2}$ Brazelton 4 claimed that paroxysmal crying that occurs in the early evening is a distinct entity from colic. We describe the relation of evening and postprandial colic to parental smoking.

\section{Subjects, methods, and results}

The study group comprised 253 infants examined at the routine paediatric consultation at 3 months of age. Mothers were interviewed and four digestive symptoms recorded-namely, regurgitation, vomiting, flatus, and crying after meals. If the mother answered "yes" to the question on crying she was asked "When your baby cries, does he or she seem to be in pain and is he or she agitated ?" Crying for two hours or more in the early evening was also recorded. Other questions concerned parity, birth weight, method of feeding (breast, bottle, mixed), conditions of delivery, and socioeconomic state, education, and smoking habits of the parents. Proportions were compared by $\chi^{2}$ tests and log linear model analysis used for studying several factors simultaneously.

Half the mothers (127) reported that their infants cried after feeding, 72 occasionally and 55 regularly; 109 seemed to be in pain and were agitated. We classified them into three grades of postprandial colic: grade 0 (not crying), 126 infants; grade 1 (occasional crying or regular crying without pain), 75 infants; grade 2 (regular crying with pain), 52 infants. There were no differences between the sexes. Postprandial and evening colic occurred independently. Postprandial colic was related to other digestive symptoms, but evening crying was not.

Parental smoking was associated with digestive symptoms (table) and particularly with postprandial colic but not with evening colic. In the 215

Parental smoking and digestive symptoms

\begin{tabular}{|c|c|c|c|c|}
\hline & \multicolumn{3}{|c|}{ No of smoking parents } & \multirow[b]{2}{*}{ p Value* } \\
\hline & 0 & 1 & 2 & \\
\hline No of infants & 136 & 86 & 31 & \\
\hline $\begin{array}{l}\text { Grade } 0 \\
\text { Grade } 1 \\
\text { Grade } 2\end{array}$ & $\begin{array}{l}90(66) \\
37(27) \\
9(7)\end{array}$ & $\begin{array}{l}33(38) \\
23(34) \\
24(28)\end{array}$ & $\begin{array}{r}3(10) \\
9(29) \\
19(61)\end{array}$ & 0.001 \\
\hline $\begin{array}{l}\text { No }\left({ }^{\circ}{ }_{0}\right) \text { with regurgitation after } \\
\text { meals } \\
\text { No }\left(0^{\circ}\right) \text { with vomiting after meals } \\
\text { No }\left(0^{\circ}\right) \text { with flatus after meals } \\
\text { No }(\%) \text { with evening crying }\end{array}$ & $\begin{array}{l}48(35) \\
19(14) \\
67(49) \\
91(67)\end{array}$ & $\begin{array}{l}44(51) \\
17(20) \\
52(60) \\
55(64)\end{array}$ & $\begin{array}{r}15(48) \\
7(23) \\
22(71) \\
18(58)\end{array}$ & $\begin{array}{l}0.06 \\
\text { NS } \\
0.04 \\
\text { NS }\end{array}$ \\
\hline
\end{tabular}

NS $=$ Not significant

* Tests for homogeneity.

families in which the mother did not smoke and the father either also did not smoke or smoked 1 to 10,11 to 20 , or more than 20 cigarettes a day the prevalence of postprandial colic (grade 1 or 2 ) was $32 \%, 45 \%, 69 \%$, and $91 \%$ respectively $(\mathrm{p}<0.001)$. When neither parent smoked (136 infants) the prevalence was $32 \%$ and when only the mother smoked (seven infants) it was $57 \%$.

Postprandial colic was less frequent in breast fed infants and those in the higher socioeconomic classes. Parents who smoked were less likely to breast feed and had a lower educational level. Postprandial colic, however, remained strongly related to each of the three factors-parental smoking, infant feeding, and socioeconomic state-after controlling for the two others. Parity, birth weight, and the conditions of delivery were not associated with either postprandial colic or evening crying.

\section{Comment}

Postprandial crying with apparent pain and agitation was related to other digestive symptoms and may be regarded as characteristic of infantile colic. The effect of parental smoking was striking. Many adult non-smokers suffer discomfort in an environment polluted by smoke or the odour of stale tobacco, and young babies are probably more susceptible because of their sensitive olfactogustatory systems. It may be hypothesised that gastrointestinal contractions are triggered by olfactory or gustatory stimulation through a vagal reflex mechanism. ${ }^{5}$

Whatever the true cause of infantile colic it may benefit families to know that parental smoking may be a factor. 1 Hide DW, Guyer BM. Prevalence of infant colic. Arch Dis Child 1982;57:559-60. Asnes RS, Mones RL. In
Pediatrics 1982;4:57-62.

3 Thomas DB. Aetiological associations in infantile colic: an hypothesis. Aust Paediatr $\mathcal{F}$ 1981;17:292-5.

4 Brazelton TB. Crying in infancy. Pediatrics 1962;29:579-88.

5 Christensen $J$. The controls of gastrointestinal movements: some old and new views. N Engl f Med $1971 ; 285: 85-98$.

(Accepted 27 fune 1984)

INSERM U 169, 94807 Villejuif Cedex, France

GILLES SAID, MD, paediatrician

ELISABETH PATOIS, BA, statistician

JOSEPH LELLOUCH, PHD, research director

Correspondence to: Dr J Lellouch. 